\title{
(可視) 光を測る
}

\section{馬 場 護 郎}

\section{1.まえがき}

光という語は, 技術的に用いられる場合でも, 用いる人 や用いられる分野でいろいろの意味で用いられているのが 実情である.しかし，光という語が元来どのような意味で 用いられ，将来どのように用いられるべきかという最低限 の合意を得ることは，これを用いる分野が近年益々増大し， 外国語との対比が必要となっている現在極めて重要である.

国際的に電気 (照明) 用語を定義した IEC 60050-8451)（国 際照明用語集) では，光に対応する仏，英，独，露語 (Lumiére, Light, Licht, c в e T) の定義として, (1)視 覚系に生じる明るさおよび色の知覚・感覚 (Perceived Light). (2)可視放射 (Visible Radiation)としており,さら に，参考として光という語は，ときに可視波長範囲外の光 学的放射の意味で用いられるが，この用法は推奨しないと している。我が国でこのIEC規格に整合する日本工業規格, JIS Z81132)を審議した際, 現状では, 可視波長範囲外の光 学的放射にも用いられていることを加味して, (3)紫外放射, 可視放射および赤外放射の総称という意味を付加した。こ こで言う光学放射 (Optical Radiation) とは，X線への移行 領域の波長約 $1 \mathrm{~mm}$ から，電波への移行領域の波長約 $1 \mathrm{~mm}$ までの波長範囲の電磁放射，可視放射とは，人の目に入っ て，直接に，視感覚を起こすことのできる放射で，一般に 短波長側を360〜 400nmの間に，長波長側を760〜830nmの 間にとるものと定義されている。一方, 我が国では従来, 光に対応する英語, Light, Luminous, Optical, Opto-, Photo- などで修飾された語を, 光で対応させている場合と, 光以外の語で対応させている場合が混在しており, Lightの 定義をどうするかで論争が行われた。この経緯については, JIS Z8113の解説に, 両論併記されて詳述されているので参 照されたい。ここでは, 日本における光の用い方が様々で あることを承知の上で, 将来における無用の混乱と, 外国 語との対応を容易にする意味で, IEC/CIE用語の原則にな るべく忠実に言葉を用いていきたい。次に必要なことは,

†株式会社村上色彩技術研究所

"Measurement Technology on AV Media (2) : To Measure (Visible) Light" by Gorow Baba (Murakami Color Research Laboratory, Tokyo)
放射量と測光量の基本的な差異を知っておくことである. 放 射量は放射の分光的広がりを，一般には波長的な重価をしな いで評価したもので，測光量は，可視放射の分光的広がりを， 標準分光視感効率 (Spectral Luminous Efficiency) $V(\lambda)$ に よる重価的評価をしたものである.したがって，放射量は物 理量であるのに対して, 测光量は, $V(\lambda)$ で重みをつけた心 理物理量である.

標準分光視感効率は, 測光標準観測者の明所視 (数 $\mathrm{cd} / \mathrm{m}^{2}$ 以上の輝度レベルに順応したときの正常視の視覚)の分光 視感効率を，古くは，CIEが1924年に規定したのに始まり， 現在は, ISO/CIE標準 ${ }^{3)}$ に等色関数の $\bar{y}(\lambda)$ として規定さ れている. 暗所視 (数 $10 \mathrm{mcd} / \mathrm{m}^{2}$ 以下の輝度レベルに順応し たときの正常視の視覚)の分光視感効率は, CIEによって 1951年 $V^{\prime}(\lambda)$ として規定されており，薄明視の場合は，明 所視と暗所視の間の值をとるとされている.

\section{2. 放射量と測光量}

放射には，時間的，空間的，分光的な広がりがあるので， 測定にあたってはこれら3つのパラメータを考慮する必要 がある。これらの点に留意して, 主な放射量と測光量につ いて説明する。主な放射量と測光量の記号，定義式，単位 を表1に示す。なお，表中の記号の添字eは放射量を, 添字 Vは測光量であることを示す。

\section{1 放射量, 光束}

放射源が空間へ放射する放射パワーを放射束と呼び，そ の単位はWである．放射束の波長的広がりを分光視感効率 で重価した量が光束である，表中にある $K \mathrm{~m}$ は最大視感効 果度といい， $V(\lambda)$ を最大の1とする波長の単色放射の $1 \mathrm{~W}$ 当たりの光束の $\operatorname{lm}$ の值である. 測光量の基準は, 古くは光 度で，黒体を基準にして光度標準電球で定められたが, 1979年に採択された測光量の基本に関する新定義では，周 波数 $540 \times 10^{12} \mathrm{~Hz}$ (空気中の波長 $555.017 \mathrm{~nm}$ ，真空中では $555.171 \mathrm{~nm})$ の単色放射の $1 \mathrm{~W}$, 光束 $683 \mathrm{~lm}$ とすると規定さ れている，暗所視の場合は， $V^{\prime}(\lambda)$ を用い，周波数 $540 \times$ $10^{12} \mathrm{~Hz}$ の単色放射を 683 暗所視 $1 \mathrm{~m} \cdot \mathrm{W}^{-1}$ とすると, 暗所視最 大視感効果度は， $K^{1} \mathrm{~m}=17001 \mathrm{~m} \cdot \mathrm{W}^{-1}$, 最大となる波長は, $507 \mathrm{~nm}$ となる．光源が全空間に放射する光束の総量は，全 光束と呼び，球形光束計などで測定される. 


\begin{tabular}{|c|c|c|c|c|c|c|c|c|c|}
\hline 放射量 & 記号 & 英語名 & 定 義 式 & 単 位 & 測光量 & 記号 & 英語名 & 定 義 式 & 単 位 \\
\hline 放射エネルギー & $Q_{\mathrm{e}}$ & $\begin{array}{l}\text { radiant } \\
\text { energy }\end{array}$ & & J(ジュール) & 光量 & $\begin{array}{l}Q_{\mathrm{v}} \\
Q\end{array}$ & $\begin{array}{l}\text { quantity } \\
\text { of light }\end{array}$ & $Q_{\mathrm{v}}=\int_{0}^{t} \Phi{ }_{\mathrm{v}} d t$ & $\operatorname{lm} \cdot \mathrm{s}$ \\
\hline $\begin{array}{l}\text { 放射束 } \\
\text { 放射パワー }\end{array}$ & $\Phi_{\mathrm{e}}$ & $\begin{array}{l}\text { radiant } \\
\text { flux } \\
\text { radiant } \\
\text { power }\end{array}$ & $\Phi_{\mathrm{e}}=\frac{d Q_{\mathrm{e}}}{d t}$ & $\begin{array}{l}\mathrm{W}(\text { ワット }) \\
\quad\left(\mathrm{W}=\mathrm{J} \cdot \mathrm{s}^{-1}\right)\end{array}$ & 光束 & $\begin{array}{l}\Phi_{\mathrm{v}} \\
\Phi\end{array}$ & $\begin{array}{l}\text { luminous } \\
\text { flux }\end{array}$ & $\begin{array}{l}\Phi_{\mathrm{v}}=K_{\mathrm{m}} \int_{\lambda_{\mathrm{S}}}^{\lambda_{\mathrm{L}}} \frac{d \Phi_{\mathrm{e}}(\lambda)}{d \lambda} \\
V(\lambda) d \lambda\end{array}$ & $\operatorname{lm}($ ルーメン $)$ \\
\hline 放射照度 & $E_{\mathrm{e}}$ & irradiance & $E_{\mathrm{e}}=\frac{d \Phi_{\mathrm{e}}}{d A}$ & $\mathrm{~W} \cdot \mathrm{m}^{-2}$ & 照度 & $\underset{E}{E}$ & illuminance & $E_{\mathrm{v}}=\frac{d \Phi_{\mathrm{v}}}{d A}$ & lx (ルクス) \\
\hline 放射発散度 & $M_{\mathrm{e}}$ & $\begin{array}{l}\text { radiant } \\
\text { exitance }\end{array}$ & $M_{\mathrm{e}}=\frac{d \Phi_{\mathrm{e}}}{d A}$ & $\mathrm{~W} \cdot \mathrm{m}^{-2}$ & 光束発散度 & $\stackrel{M_{\mathrm{v}}}{M}$ & $\begin{array}{l}\text { luminous } \\
\text { exitance }\end{array}$ & $M_{\mathrm{v}}=\frac{d \Phi_{\mathrm{v}}}{d A}$ & $\operatorname{lm} \cdot \mathrm{m}^{-2}$ \\
\hline 放射強度 & $I_{\mathrm{e}}$ & $\begin{array}{l}\text { radiant } \\
\text { intensity }\end{array}$ & $I_{\mathrm{e}}=\frac{d \Phi_{\mathrm{e}}}{d \Omega}$ & $\mathrm{W} \cdot \mathrm{sr}^{-1}$ & 光度 & $\begin{array}{c}I_{\mathrm{v}} \\
I\end{array}$ & $\begin{array}{l}\text { luminous } \\
\text { intensity }\end{array}$ & $I_{\mathrm{v}}=\frac{d \Phi_{\mathrm{v}}}{d \Omega}$ & cd (カンデラ) \\
\hline 放射輝度 & $L_{\mathrm{e}}$ & radiance & $L_{\mathrm{e}}=\frac{d \Phi_{\mathrm{e}}}{d A \cdot \cos \theta \cdot d \Omega}$ & $\mathrm{W} \cdot \mathrm{m}^{-2} \cdot \mathrm{sr}^{-1}$ & 輝度 & $\begin{array}{c}L_{\mathrm{v}} \\
L\end{array}$ & luminance & $L_{\mathrm{v}}=\frac{d \Phi_{\mathrm{v}}}{d A \cdot \cos \theta \cdot d \Omega}$ & $\mathrm{cd} \cdot \mathrm{m}^{-2}$ \\
\hline
\end{tabular}

放射の分光密度 $X_{\mathrm{e}}(\lambda)$ は $X_{\mathrm{e}}(\lambda)=d X_{\mathrm{e}} / d \lambda$ (単位: $X_{\mathrm{e}}$ の単位 $\cdot \mathrm{nm}^{-1}$ ) とする.

$V(\lambda)$ : 標準分光視感効率 $K_{\mathrm{m}}$ : 最大視感効果度 $=683 \mathrm{~lm} \cdot \mathrm{W}^{-1} A$ : 面積 $t$ : 時間

$\Omega$ :立体角 $\lambda$ : 波長 $\theta:$ : 法線からの傾き角

(色彩科学ハンドブッグ)

\section{表1 主な放射量と測定量}

\section{2 放射エネルギー，光量}

定常な放射束と時間との積は放射エネルギーで，単位は $\mathrm{J}=\mathrm{W} \cdot \mathrm{S}$ あ゙る. 光束の時間積は光量で, 単位は $\mathrm{lm} \cdot \mathrm{s}$ あ゙ある. 光電効果や視覚の効果は, 放射束, 光束に比例して起こる が，写真や紅斑効果などは放射エネルギー，光量に比例し て起こる．放射パワーと放射エネルギー，光束と光量とは しばしば混同されることがあるので注意すべきである。

\section{3 放射強度, 光度}

放射源の大きさがごく小さいとき，放射源を頂点とする 円錐内に発散する放射束と立体角の比，すなわち放射束の 立体角密度を放射強度といい，その単位はW· $\mathrm{sr}^{-1}$ である。 光束について同様に定義したものが光度で，その単位はcd である．放射源から全空間に向かって均等に発散する放射 源については, 全放射パワーは, 放射強度の $4 \pi$ 倍となる. $1 \mathrm{~cd}$ の光源から，全空間に均等に発散するときの光束は，4 $\pi \operatorname{lm}$ である。

\section{4 放射照度, 照度}

受光面上の 1 点を含む面要素に入射する放射束を，その 面要素の面積で割った值，すなわち放射束の面密度を放射 照度といい, その単位は $\mathrm{W} \cdot \mathrm{m}^{2}$ である. 光束について同じ 定義をした場合，その值を照度といい，その単位は $\mathrm{lx}=\mathrm{lm}$. $\mathrm{m}^{2}$ である．放射照度および照度は面に放射が入射する場合 について定義されているが，面から発散するときにこれに 相当するものを，放射発散度，光束発散度といい，その単 位は同様である。

\section{5 放射輝度, 輝度}

発光面上，受光面上または放射の伝搬路の面上において， 表1に記載された式で定義される值を，放射輝度または輝 度といい，その単位は $\mathrm{W} \cdot \mathrm{m}^{-2} \cdot \mathrm{sr}^{-1} ま た は \mathrm{~cd} \cdot \mathrm{m}^{-2}$ あ゙あ。す なわち，面の法線とビームのなす角が $\theta$ であった場合，面
の射影に対する放射強度または光度の割合となる。

放射量や測光量を測定するときに，基本的な法則として 逆二乗則と余弦則がある，逆二乗則は，点光源から空間へ 発散する放射の密度は, 放射光源からの距離の 2 乗に反比 例して減少するというもので, 実際の面積をもった光源で も発光面の寸法と距離の比が大きくなければ成立する.

余弦則は, 受光面の法線に対してある角度で入射する放 射の受光面上での密度は, 法線入射のときの密度の余弦に 比例して減少するというものである，乳白アクリル板のよ うな透過面や，硫酸バリウム粉末を圧着したような反射面 は，入射した光を散乱させて透過または反射するので拡散 透過 (反射) 面と呼ぶ. 拡散面に任意の方向から光を入射さ せたとき, 散乱した光の放射強度または光度が, 面の法線 方向で最大となり, 法線からある角度傾いた方向の放射強 度または光度がその角度の余弦に比例するとき, その面を 均等拡散面 (ランベルト面) と呼ぶ. 均等拡散面のうち, そ の透過 (反射) 率が1である面を, 完全拡散透過 (反射) 面と 呼び，透過 (反射) 特性を表すときの基準となる. 完全拡散 面は，4フッ化エチレン粉末圧着面で略それに近いものを 実現できるが，完全拡散透過面 (界面での反射や層内での 吸収のない) は実在しない。

実際に放射測定や測光を行うときには，次のような配慮 が必要である。

(1) 波長的な広がりに対する配慮

測光は放射を分光視感効率の重みをつけて評価するもの で, 受光系の分光応答度は, 分光視感効率に相似していな

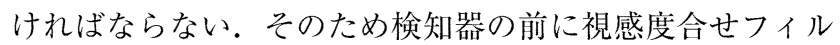
夕を置いて，総合的な分光応答度を分光視感効率に近似さ せる刺激值直読方式か，放射を分光測定して，計算によっ て測光值を求める分光方式を用いる．刺激值直読方式は, 


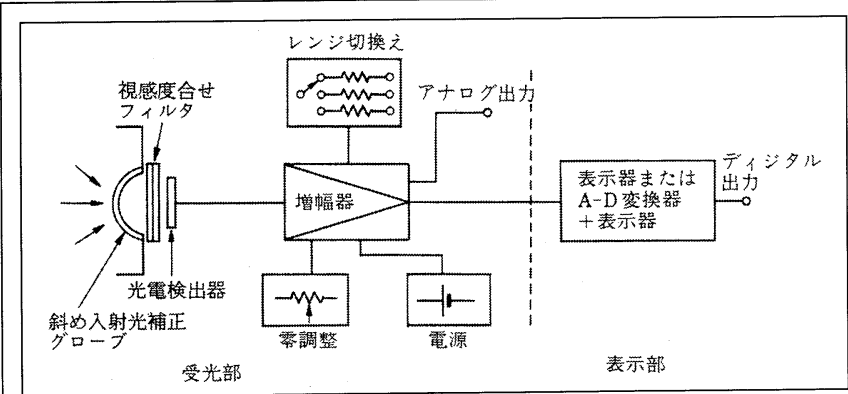

図 1 照度計の基本的な構成 (光の計測ハンドブック 5 )

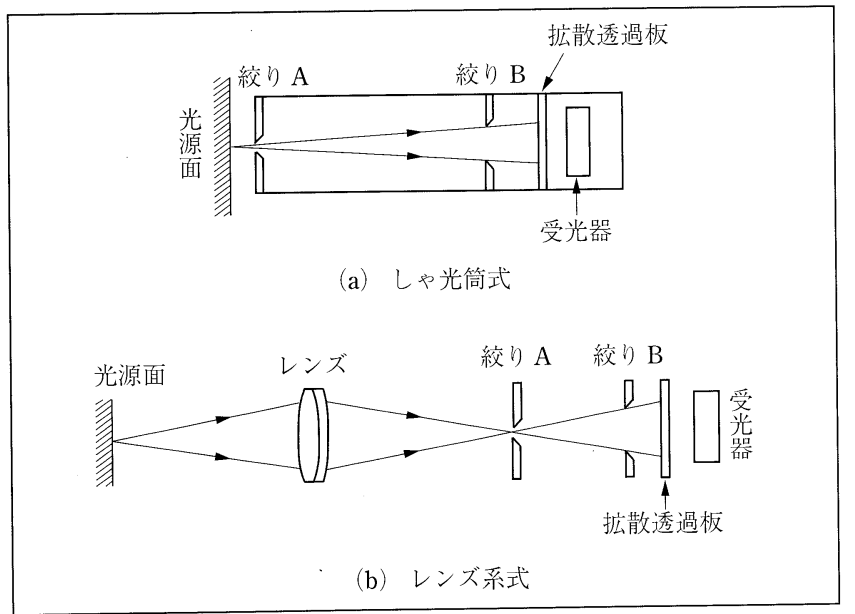

図2 輝度測定の原理

(光学的測定ハンドブッグり)

簡単な色ガラスフィルタの組合せでは分光特性を正確に合 致させることは困難で, 分光特性を合せるため複雑な色ガ ラスフィルタの組合せにすると透過率が低下して測定の感 度が低下する。しかし, 放射の分光特性に波長について起 伏が少ないときや, 校正に用いた標準光源の分光特性に近 いときは, 単純な装置で, 測定範囲の広い測定器を作るこ とができるので，照度計や輝度計に多用される，研究機関 などでは，分光応答度を極めて正確に調整した大型の輝度 計を用いている例もある。

放射測定では, 受光系の分光応答度が波長に関して一様 な熱型検知器を用いる場合のほかは, 分光方式が用いられ ることが多い．分光方式は以前は高速に波長走査のできる モノクロメータと検知器を組合わせたものが用いられた が, 現在では分散素子によるスペクトルの結像面にアレイ 形検知器を置いて, 瞬間的に波長走查のできるポリクロメ 一夕を用いることが多い. 分光方式によれば分光応答特性 を，計算によって任意に選択することができるので，各種 の放射量, 測光值, 任意の波長特性を持つ効果度に対応で きる.しかし，分光方式では原理的に1個の受光素子が受 ける放射パワーは微小となるので，微弱な放射を測定する 場合はS/N比が低下することは避けられない。

(2) 空間的な広がりに対する配慮
照度計では，受光面の前に種々の形状の拡散板を置いて 余弦則からの外れを補正する。しかし，余弦則に完全に合 致させるには, 受光器の前面に完全拡散透過面を密着しな い限り不可能なので, 実際の照度測定に当たっては, 測定 しょうとする入射光の方向性と照度計の余弦則の適用でき る範囲を考慮しなければならない。

照度計の基本的な構成を図1に示す。

輝度計には，放射源に近接して測定する遮光筒式と，レ ンズ系により離れた位置から测定するレンズ系式とがある (図2). 何れの場合も輝度計には視野の大きさを制限する 絞り $\mathrm{A}$ と, 開き角を制限する絞りBがある。厳密に言えば, 輝度測定は両者の絞りを最小にする必要があるが，一方で は輝度測定では，ダイナミックレンジを広くとることを要 求される場合が多いので, 絞りの大きさは，0.1度程度から 数度まで可変または固定のものが用いられている，輝度一 定の面を測定する場合は問題ないが，視野内に光源があっ たり，輝度の分布が急変する面の測定の場合は注意しなけ ればならない。

(3) 放射測定および測光の標準

放射測定および測光の標準には, 大別して黒体放射源と タングステン電球による標準があるが，黑体放射源は公的 な研究機関や特定の事業者において1次標準器として使用 されるもので，一般には後者が用いられる．放射測定にお いて重要なものは, 分光放射照度標準電球および分布温度 標準電球で, 特に前者の分光放射照度の值は産業技術総合 研究所の標準に基いて日本電気計器検定所が供給し, さら にこれに基いて認定事業者がその標準の值を供給する．測 光の標準には, 光度, 分布温度, 全光束, 全放射照度の電 球がある、放射の測定器のメーカは, 計量法によって国か ら認定された認定事業者として, 光度, 照度, 分光放射照 度, 分布温度などの計量標準の供給および校正サービスを 行っている.

上記の標準は何れも黒体放射源に基礎を置くものである が，経年変化があるため校正を繰返す必要があり，かつ温 度目盛の精度により值の精度に限界があるので, より安定 なシリコンフォトダイオードの分光応答度を標準とするこ とが行われている，我が国で進められている方法は，極低 温放射計から直接検知器の分光応答度を校正し, 絶対分光 応答度 $(\mathrm{A} / \mathrm{W})$ を值付けする。この方法により，黒体放射 源によらずにより高精度な光度・光束単位の設定が可能と なり，今後の実用化が期待されている.

現在市販されている照度計, 輝度計の性能の比較につい ては，「光の計測ハンドブック5)」に詳述してある.

なお，照度計および輝度計の性能評価法については， CIE出版物No.6 $69^{7)}$ が参考となる.

\section{3. 測 色}

色の測定には，光源色の測定と，物体色の测定がある. 
光源色とは，1次または 2 次光源からの放射を測定すること で，物体色とは，照明された物体から反射または透過した 放射を測定することである。ここで言う光源色とは，実際 に光源 (2次光源を含む) から発する色を意味し，見えのモ ードとして光源色モードで知覚されるかは, 問題としてい ない.したがって，ディスプレイの測色にも応用できる。

3.1 光源色の測定方法 (JIS Z8724：1997 色の測定方 法一光源色 参照)

光源色の測定方法には, 分光測色方法と刺激値直読方法 があるが，正確さが必要なときは，分光測色方法を用いる.

これは，光源色では物体色よりも分光分布に起伏がある もの，例えば輝線スペクトルを含省放電灯などが多いので， 刺激值直読方法の場合のルータ条件からの外れが，測定結 果に影響を与えるからである.

刺激值直読方法掞よび分光測色方法による光源色測定の 配置を図3および図4に示す。

分光測色方法では，標準光源抒よび試験光源からの放射 を交互にモノクロメータまたはポリクロメータの入射スリ ットに導き, 分光放射パワーの相対值または絶対值を求め, 測色計算によって三刺激値を求める. 標準光源としては, 分光放射照度標準電球, 分布温度標準電球またはこれらを 用いて值付けされた電球を用いる．分光放射パワーが絶対 值である場合は, 三刺激値の Yは, 計算值に最大感度効率 （6831m/W）を乗じたとき測光值となる. 分光測色方法の場 合, 被験放射の測定装置への導入方法は, 積分球を用いる か, 白色拡散板で反射させるか, 拡散板を透過させて, 入 射スリットから入る放射を均一化する。刺激值直読方法で は, ルーター条件からの外れを規制するために, 光電色彩 計の分光応答度と等色関数との偏差を, 等色関数と波長範 囲を区別して許容条件をJISで定めている．光源色測定の 際の標準光源, 校正用光源には, 白熱電球だけではなく蛍 光灯や高輝度放電灯が使用されるが，これらの光源は点灯 方法などによる変動があるので, JISでは付属書にその方 法を説明している. 光源色の白色点は, 分光パワーが波長 に関係なく一定な放射で，その色度座標は， $x=0.3333$ $y=0.3333$ である. $x y$ 色度図よりも均等な色度図を用いると きは, CIE 1976 UCS色度図 ( $u^{\prime} v$ 色度図) を用いる。この色 度図は, $x y$ 色度図の射影变換であるので, 光源色の加法性 は保持される. 光源色の場合, $L^{*} a^{*} b^{*}$ 空間, $L^{*} u^{*} V^{*}$ 空間を 用いることは好ましくない．

\section{2 物体色の測定方法 (JIS Z8722-2000：色の測定方法 一反射および透過物体色 参照)}

物体色が光源色と大きく異なる点は，物体色はそれを照 明するイルミナントを約束しなければならないこと, 反射 物体色の基準は完全拡散反射面, 透過物体色の基準は空気, 溶媒または完全拡散透過体であることである。物体の反射 (透過)は一般に, 同時に正反射 (透過) 性と拡散反射 (透過) 性を持つ混合反射 (透過)である. 以前は, 正反射成分は正

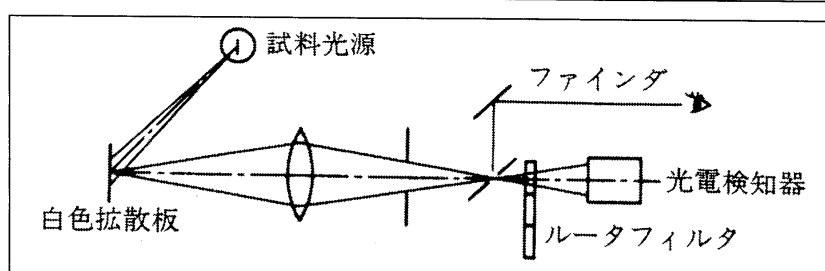

(a) 輝度計形

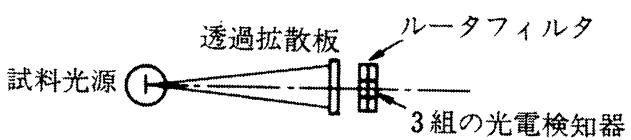

(b) 照度計形

図 3 刺激値直読方法による光源色測定の例 (光の計測ハンドブックら)

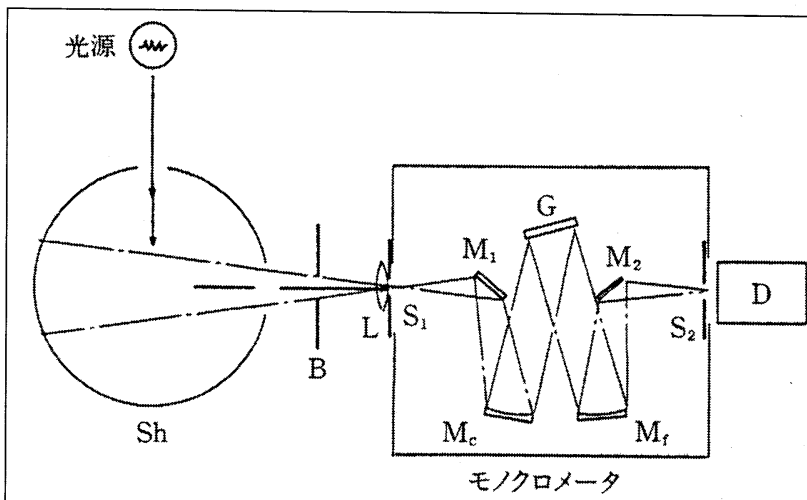

$\mathrm{Sh}$ : 積分球 $\mathrm{B}$ : 遮光絞 $\mathrm{G}$ : 回折格子

$\mathrm{S}_{1}, \mathrm{~S}_{2}$ : 入, 出射スリッ卜 $\mathrm{M}_{1}, \mathrm{M}_{2}$ : 平面ミラー $\mathrm{M}_{\mathrm{c}}$ : コリメータミラー $\quad \mathrm{M}_{\mathrm{f}}:$ フォーカシングミラー $\mathrm{D}$ : 放射検出器 L : フィールドレンズ

図4 分光測色方法による光源色測定の例 (JIS Z 8724)

反射方向の近くに集中し，拡散反射成分は均等拡散に近い と想定して，物体色測定の場合の照明および受光の幾何条 件が約束されたが，その後この仮定に合致しない物体が多 いことが判ってきたので異なる考え方が出てきた。反射に ついて言えば，反射率とは入射する光束と反射する (全) 光 束の比とし，幾何条件の0-D，D-0がこれに相当する（全光 束を表すときDとし，正反射分を除いた全光束を表すとき はdとして区別する)，輝度率とは，表面の与えられた方向 への輝度の, 同じ条件で照明された完全拡散反射体の輝度 に対する比と定義し，幾何条件の45-0，0-45がこれに近い。 しかし, 物体の反射特性を現わし, かつ実際に測定されて いるものは，物体表面に頂点をおく与えられた錐体で範囲 を定められた立体角内への反射光束が測定されており，こ れを反射率係数と定義する. 反射率係数は，錐体の頂角の 立体角が $2 \pi$ に近づけば反射率となり，0に近づけば輝度率 になる、したがって，ほとんどの反射物体色の測定は，反 

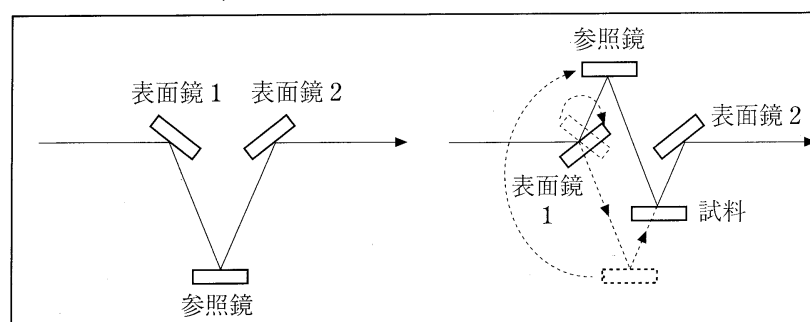

(a) $\mathrm{V}-\mathrm{N}$ 法

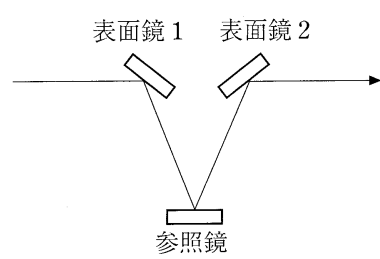

表面鏡 1 表面鏡 2

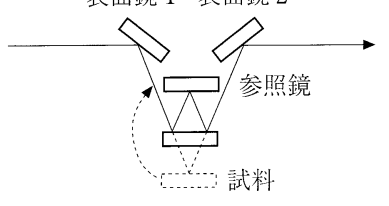

(b) V-W 法

図 5 正反射率の直接判定法

(色彩科学ハンドブック 4)

射率係数の測定であると言える。ディスプレイなどの表面 の与えられた方向への輝度を, その照度で割った量は輝度 係数である。

物体色の測定にも, 分光測色方法と刺激值直読方法とが あり，分光測色方法は，第1種分光測光器 (例えばモノクロ メータ)を用いる場合と，第2種分光測色器（例えばポリク ロメータ）を用いる場合とに分かれている．これは，第2種 分光測光器が，任意の波長において波長精度や，有効波長 幅の検定が困難であることと，迷光を充分に除去できない ので測色の正確さが劣るためである．物体色の測定におい て最も重要なのは，反射 (透過) 率尺度の正しさで，これに は，(1)100\%近くの尺度の正しさ，(2)直線性，(30\%付近の 目盛りの正しさが含まれる。(1)については，絶対反射率測 定法により值付けされた白色板により校正された白色板で 検証する．絶対反射率測定方法についてはCIE出版物No.44 8) がある. 現在, 各国立研究所の間で日本も参加して, 積 分球を用いた絶対反射率測定方法によって白色板の拡散反 射率測定の相互比較が行われている ${ }^{9)}$. 正反射率の直接測 定法には，図5に示す様々な方法があり，V-N法では正反射 率が，V-W法では正反射率の 2 乗が測定されている。この 方法は，市販の分光測光器に付属装置を付加して測定でき る. 透過率の高い試料を, 積分球を用いた単光束の測定器 で空気を標準として測定すると，試料の界面反射によって 誤差を生じるので，補償することが必要である ${ }^{10)}$. (2)につ いては，ダブルアパーチャ法などで校正された分光测光器 で值付けされた灰色ガラスフィル夕か, これを用いて值付 けされた死色反射試料を用いて検証する。(3)特に彩度が 高い試料や，暗色の反射試料の場合に重要で，まず，黑色 体を試料位置に置いて $0 \%$ 正しさを検証し，次に分光反射 率の低い標準試料で0\%付近の反射率尺度の直線性を検証す
る。第2種分光測光器を用いた測定器では，迷光の除去が 不充分であったり，波長によって $\mathrm{A} / \mathrm{D}$ 変換誤差が大きいと 測色值に大きな影響を与える，迷光は，測定光路中にシャ ープカットフィルタを入れて検証することができる．波長 誤差は，第1種分光測光器では，スペクトルランプや波長 検定用フィルタ（ホロミウムフィルタなど）を用いて波長精 度と有効波長幅を検証する。第2種分光測光器では通常, 使用者が波長により反射率の変化の大きい, 黄, 赤, 赤紫 などの反射試料を子め第 1 種分光測光器で測定しておき, これを標準試料として第2種分光測光器の波長の正しさを 確認する.

\section{4，測定試料の光学特性}

\section{1 反射 (透過) 光の空間分布}

従来の物体色の測定は，ほとんど完全拡散反射（透過） 光体に基礎を置いて考えられてきた。また，一般の物体の 反射光は，表面からの反射光と層内からの反射光で構成さ れ，表面反射光の空間分布は表面形状で決まり，層内から の反射光は，ほほ均等拡散であるとしてきた。しかし，実 在の試料からの反射光の空間分布は，この仮定にしたがっ ているものは少ない. 特に, 反射光の異方性を応用したメ タリックペイントなどでは，まったく異なる反射光の空間 分布をする。

したがって，物体色の測定に当たっては，測定の幾何学 条件と, 試料反射光の空間分布を考慮しなければならない. CRTディスプレイからの光は, 蛍光面からの発光はほぼ均 等拡散するが，管壁ガラスの屈折，反射によって方向性が 変化する. LCディスプレイからの光は，もともと指向性を 持っているが，拡散性を良くすると法線方向の輝度が低下 する。これらの試料の測定には，照射角・受光角を変化さ せて測定できる変角測色装置を使用する.

\section{2 蛍光物体色}

蛍光物体色は，試料の反射色と，蛍光色とが合成された もので，その蛍光成分は照射光の分光分布によって変化す る.したがって測定の際の照射光は, 測定用イルミナント (例えばD65光) と相似の分光組成であることが原則である. 蛍光物体色を積分球を用いた測色器で測定すると, 試料か らの蛍光が積分球内壁で反射して再照射するので, 誤差を 生じる。これを防ぐには，積分球内表面積に対して試料開 口面積を充分に小さくする，紙や白色布のほとんどは蛍光 増白されているので，その照射光の近紫外部の分光分布は, 標準イルミナントのその部分に近似していなければならな い. 蛍光を含む白色紙の白さの評価には, 室内昼光の近紫 外部のパワーがD65のそれよりも小さいとの理由で, C光 によるとしている，蛍光物体の测定は，反射光と蛍光成分 とを分離して測定できる2分光器法によることが基本にな るが，1分光器で測定する方法が，JIS28717「蛍光物体色の 測定方法」に規定されている。 


\section{3 偏 光}

LCディスプレイは原理的に偏光を利用しているので，そ の光が偏光しているのは当然であるが, 自然物の反射光も 偏光していることがある. 正反射光は鏡面反射角によって 偏光特性が変わるので，正反射光を含む割合の多い場合は 注意しなければならない.モノクロメー夕は元来偏光特性 を持っているので, 必要な場合は偏光子により偏光面を変 えて測定する.

\section{4 干渉, 回折}

薄膜による干渉色を応用したものに，カラーステンレス， パールマイカペイントなどがある. カラーステンレスは，ス テンレス鋼板の表面に酸化皮膜をつけたもので, 膜厚により 種々の干渉色を示し，それが正反射方向に強調されるので金 属色感を与える. パールマイカはマイカ表面に二酸化チタン 被膜をつけたもので, 観察方向により干渉色の強度が変化す る. モルフォ蝶の羽根には規則的な溝があって白色光を回折 し，観察方向によってその色が大きく変化する.

\section{5 ブロンジング}

フタロシアニンやキナクリドンなど高屈折の顔料は，塗 膜中にあるときは界面での屈折率差が小さいので通常の顔 料と同様な反射色を示すが, 塗膜表面に露出して空気と接 すると屈折率差が大きくなるため塗膜中とは補色をなす反 射色を呈し，これをブロンジングという。ブロンジングは 正反射方向で強く観察されるので金属色感がある.ブロン ジングの測色には, 変角分光測色装置を用いるか, 積分球 の光トラップを着脱して行う.

\section{6 半透明物体}

石けん, バター, ジュース, 皮膚などは, 層内の光は微細 な粒により散乱するが, その様相は粒径によって変化する. これは波長と粒径によって散乱方向, 散乱強度が変化する ためで，観測方向で色が変わって見えることがある．これ らの物体の測色には, 照射面積と観測面積の比が影響する。

\section{7 試料の形状}

糸や織物のように，明らかに組織の見える試料では入射面 と組織の方向によって測定值が変化するので，あらゆる方 向で測定するか,試料を面内で回転して測定值を平均化する. 粉体や綿などを測定する場合，表面を平らにするためガラ スでカバーすると, ガラスによる光量損失. 充てん率の違 いなどで測定值が変化する，表面にテクスチャのあるプラ スチック成形面や模様塗料などは，テクスチャの大きさと， 照射面積, 観定面積の違いによって測定值が変化する.

\section{8 試料の恒常性}

染料濃度の薄い染色物などでは，光の照射によって染料 が変色したり，退色することがある。このような場合，試 料が蛍光を発しないときは, 白色光照明よりも照射エネル ギーの小さい単色光照明が望ましいときがある. 分光反射 (透過) 率分布に急峻な変化のある色ガラスフィル夕や，陶 器面などには, 温度によって切れ目波長が左右に移動する
サーモクロミズムが測定されることがある.サーモクロミ ズムは温度に対し可逆的であることが多い.

\section{5. 知覚色と測色值}

測色值と，目で見た色との間に違和感があることは，良 く経験される。その原因の1つは，測色值は等色関数に基づ いて物理量を変換した心理物理量であるのに対して，知覚 色は現感に基く心理量であるからである，CRTディスプレ イの色は測定する側からは光源から発する光の光源色とし て扱うが，見えのモードからは,光源というモードはなく， 画面という物体色モードだと言える。近年，色順応に関す る研究が活発で, 測色值と知覚色と間の階段を1段上がった 感がある. 今后，この分野の研究が盛んに進歩して，知覚 色と测色值の関係が明らかになって行くことが期待される.

\section{6.むすび}

光と色の測定については，古くから研究されていたもの のまとまった説明がそしかった。これはこの分野が，電気， 照明, 光学. 物理など各分野にまたがった問題で, 総合的 に整理されなかったからであろう。近年，さらに画像分野 での色の取扱いが急になってきて, 今一度見直しを必要と される分野でもある.ここでは光とは何かという基本的な, 問題を出発点として, 今までに構築された技術を紹介し, 今考えられる問題点を列拳した。したがって，一般の技術 書や規格にある説明は，重複をさける意味で除いてある. これらについては，末尾にあげた文献を参照して載きたい。

(2001年11月 12 日受付)

\section{〔文 献〕}

1) IEC 60050-845, International Electrotechnical Vocabulary, Chapter 845 : “Lighting，共同出版された，Publication CIE，17-4，International Lighting Vocabularyと同じ.

2）JIS Z8113-1998：照明用語

3) ISO/CIE $10527: 1991$, CIE Standard Colorimetric Observers

4）日本色彩学会編：“新編色彩科学ハンドブック第2版”東京大学出版 会 (1998)

5）照明学会編：“光の計測ハンドブック”，日本理工出版会 (1990)

6）“光学的測定ハンドブック”，朝倉書店（1981）

7) "Methods of Characterizing Illuminance Meters and Luminance Meters", Publl CIE, 69-1987

8) “Absolute Methods for Reflection Measurement", Publl CIE，44-1979

9）小貫他：光放射標準と計測技術の研究； “測光 - 放射標準”, 電子技 術総合研究所彙報, 64, 8, pp.57-63

10) ISO13468-1 : Plastics-Determination of the Total Luminous Transmittance of Transparert Materials-Part1 ; “Single-Beam Instrument” (1996)

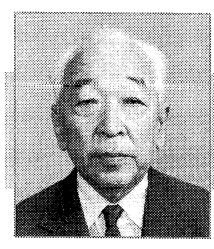

黛場 護郎 1954年, 東京大学卒業。同年, 日 本電子測器 (株) 色彩部入社. 1956年, (株) 村上 色彩技術研究所設立，人社. 1971 年，(株) 日立製 作所那坷工場光学装置設計部。1988年，(株) 村上 色彩技術研究所顧問。その間，色彩・光沢など見え に関する測定装置の開発設計に従事.

〔お詫びと訂正〕前号の講座95ページの表2 9 行目の「K」(キロ) は「k」 (編集委員会) の䛣りでした。扣詫びして訂正させていただきます。 